\title{
Editorial
}

\section{Which country for holding companies?}

Yann Kergall, Bureau Francis Lefebvre, Paris

EC member as well as non EC Member States are in a fair competition to attract on their territory holding companies, for they supposedly generate employment as well as financial flows.

Three major types of holding companies should be distinguished:

- companies controlling a domestic group located in a country where provisions provide for tax consolidation of groups results i.e. the french 'intégration fiscale', the German Organschaft, the Dutch fiscal unity exemption, the UK group relief etc. These regimes mainly satisfy group managing purposes and often constitute a deciding factor when choosing the location of an active business investment. Tax consolidation in the home country is seldom a deciding factor for the location of the subsequent types of holding companies.

- 'Pure holding companies' which are controlled by non-residents which have holdings in countries other than the one where the holding company is located.

- 'Mixed holding companies' (i.e. a company that does not confine its activities to owning stocks in other companies) which are either directly at the top of the tax integrated groups in its country or manage and control participations relevant to foreign investments.

Competition between states mainly appears on the specific point of the location of 'pure' or 'mixed' holding companies. The question is: how to choose the best country?

There are several non fiscal criteria such as:

- the political stability of the country;

- the range of legal provisions as well as its rigour and flexibility;

- the quality of the legal, fiscal and accounting services;

- the communication network;

- hotel facilities, the gastronomic reputation of the country and the like.

With respect to fiscal criteria, most tax adviser would primarily point out the tax burden on dividend flows and the significance of considering just as much the applicable tax regime to the holding company itself as to the input and output taxes withheld at source. Any sophisticated computer software could somehow optimise dividend flows on variably realistic basis. According to our experience, this criterion is however not of greater relevancy. It is just one among others.

When choosing a country, one should keep in mind the subsequent criteria:

- the taxation of financial products;

- the taxation of financial expenditures borne when acquiring domestic or foreign shares;

- the tax rules for thin capitalization;

- anti tax-haven provision for investors of heavily taxed countries;

- taxation of capital gains as well as deduction of capital losses;

- the application of tax treaties and their limits (anti-abuse provisions);

- the implementation of tax credits allowed by domestic law or tax treaties;

- wealth tax;

- capital transfer tax on incorporation and winding up.

Another criterion should be added to the foregoing: the stability of the tax rules of a country i.e. where it is not likely to experience any sudden changes in the law. Ruling procedures somehow tend to reinforce the fiscal stability of a country but only for a limited period of time.

When reviewing these criteria, it appears that no country offering specific holding company regimes answer simultaneously to all of them in a satisfactory way.

However, a judicious choice can generally be made when the aim, 'pure' or 'mixed' holding company, is well defined, and when the fiscal or non-fiscal criteria are carefully analysed.

Wishing that this pragmatic approach shall avoid an overbiding among countries and professionals, otherwise it shall ultimately lead to the disappointment of the investors. 